\title{
Species concepts and speciation factors in cyanobacteria, with connection to the problems of diversity and classification
}

\author{
Petr Dvořák • Aloisie Poulíčková $\cdot$ Petr Hašler $\cdot$ Mattia Belli $\cdot$ \\ Dale A. Casamatta $\cdot$ Alessio Papini
}

Received: 22 July 2014/Revised: 10 February 2015/ Accepted: 13 February 2015/

Published online: 3 March 2015

(C) The Author(s) 2015. This article is published with open access at Springerlink.com

\begin{abstract}
The cyanobacteria are the most important prokaryotic primary producers on Earth, inhabiting a great diversity of aquatic and terrestrial environments exposed to light. However, the evolutionary forces leading to their divergence and speciation remain largely enigmatic compared to macroorganisms due to their prokaryotic nature, including vast population sizes, and largely asexual reproduction. The advent of modern molecular techniques has facilitated an understanding of the important factors shaping cyanobacterial evolution, including horizontal gene transfer and homologous recombination. We review the forces shaping the evolution of cyanobacteria and discuss the role of cohesive forces on speciation. Further, while myriad species concepts and definitions are currently used, only a limited subset might be applied to cyanobacteria due to their asexual reproduction. Additionally, concepts based solely on phenotypes provide insufficient resolution. A monophyletic species concept which is universal may be ideal for cyanobacteria. Actual identification of the cyanobacteria is difficult due to cryptic diversity, lack of morphological variability, and frequent convergent evolutionary events. Thus, applied molecular techniques such as DNA barcoding will be useful for identifications of environmental samples. Lastly, we show that the real biodiversity of the cyanobacteria is widely underestimated, due in part to low sampling efforts, sensitivity to the molecular markers
\end{abstract}

Communicated by Anurag chaurasia.

Electronic supplementary material The online version of this article (doi:10.1007/s10531-015-0888-6) contains supplementary material, which is available to authorized users.

P. Dvořák · A. Poulíčková $(\bowtie) \cdot$ P. Hašler

Department of Botany, Faculty of Science, Palacký University Olomouc, Šlechtitelů 11,

78371 Olomouc, Czech Republic

e-mail: aloisie.poulickova@upol.cz

M. Belli · A. Papini

Department of Plant Biology, University of Florence, Via La Pira 4, Florence, Italy

D. A. Casamatta

Department of Biology, University of North Florida, 1 UNF Drive, Jacksonville, FL 32224, USA 
employed, and the species definitions employed by researchers. In conclusion, we anticipate a rapid increase in cyanobacterial taxa described and large revisions of the system in the future as scientists adopt a common approach to cyanobacterial systematics.

Keywords Cyanobacteria $\cdot$ Species concept $\cdot$ Evolution $\cdot$ Speciation $\cdot$ Biodiversity

\section{Introduction}

The Cyanobacteria (also known as the Cyanophyceae, Cyanophyta, cyanoprokaryota, bluegreen algae or blue-green bacteria) are prokaryotes possessing oxygenic photosynthesis, while sharing similar habitats to eukaryotic algae (Kauff and Büdel 2011). Moreover, cyanobacteria can live in some of the most extreme habitats on earth (Seckbach 2007). On the basis of fossil records, Schopf (2000) estimated that cyanobacteria may have evolved 3.5 BYA, making them the oldest oxygen producing photosynthetic microbes, and significant contributors to the sudden increase in atmospheric oxygen during the Great Oxidation Event (Bekker et al. 2004; Kauff and Büdel 2011).

The cyanobacteria exhibit remarkable variability in morphology and ultrastructure, from unicellular to filamentous forms (Figs. 1, 2). They may also possess intercellular connections or microplasmodesmata, considered a sign of multicellularity (Nürnberg et al. 2014). Moreover, some genera exhibit morphological and functional cell differentiation such as heterocytes (adapted to nitrogen fixation) and akinetes (resting stage cells) (Whitton and Potts 2000).

The purpose of this paper is three-fold. First, we will review the most recent literature relating to the evolutionary processes forming bacterial (and cyanobacterial in particular) species. Second, we will evaluate their application in cyanobacterial taxonomy, distribution, species concepts and species definitions. Third, we will discuss some practical aspects of cyanobacterial taxonomy and systematics.

\section{Species concept in (cyano)bacteria}

Some authors postulate that all prokaryotes are species-less or fuzzy (e.g. Hanage et al. 2005; Konstantinidis and Tiedje 2005; Hanage 2013), because they lack ecologically or genetically coherent groups. Such "fuzziness" might be apparent in ambiguous ecological boundaries among species, which was suggested by Cohan and Perry (2007) and Kopac et al. (2014). For cyanobacteria, the most obvious phenotypic features (i.e. cell morphology) may at times be phylogenetically uninformative when compared to phylogenies generated by $16 \mathrm{~S}$ rRNA gene data, which is the currently accepted "Gold-standard" in bacterial systematics (e.g. Honda et al. 1999; Robertson et al. 2001; Kim et al. 2014).

Moreover, species identifications might be complicated by the analyses used, with some traditional methods lacking species-level resolution. For example, Hanage et al. (2005) showed that multilocus sequence analysis is required to distinguish highly recombinant species of the human inhabiting bacterium Neisseria spp. Similarly, marine picoplanktic Synechococcus is composed of several ecological and geographical lineages, which may be recognized only based upon multilocus sequence analysis (Mazard et al. 2012). 


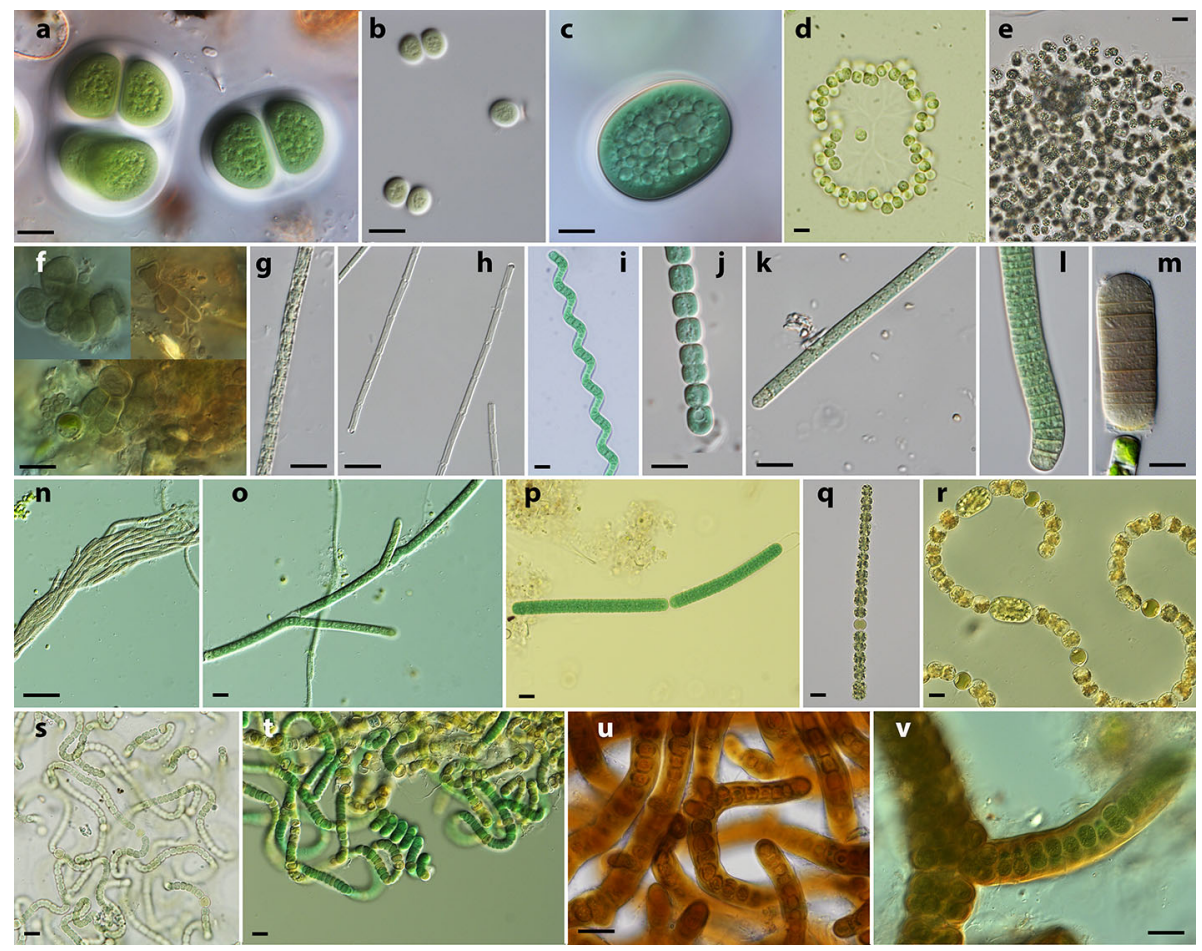

Fig. 1 Illustration of morphological diversity in cyanobacteria. Groups (orders) follow Rippka et al. (1979). I. Chroococcales: a Chroococcus subnudus, b Ch. limneticus, c Cyanothece aeruginosa, d Snowella litoralis, e Microcystis aeruginosa. II. Pleurocapsales: f Pleurocapsa minor. III. Oscillatoriales: g Planktothrix agardhii, h Limnothrix redekei, i Arthrospira jenneri, j Johanseninema constricum, k Phormidium sp., l, m Oscillatoria sp., n Schizothrix sp., o Tolypothrix sp., p Katagnymene accurata., IV. Nostocales: q Dolichospermum planctonicum, r Dolichospermum sp., s Nostoc sp., t Nodularia moravica. $V$. Stigonematales: $\mathbf{u , ~ v ~ S t i g o n e m a ~ s p . ~ S c a l e ~ b a r ~} \mathbf{a}-\mathbf{u}=10 \mu \mathrm{m}, \mathbf{v}=20 \mu \mathrm{m}$. (Color figure online)

On the other hand, since the frequency of horizontal gene transfer (HGT) and homologous recombination (HR) decreases with the genetic distance suggests coherence within evolutionary lineages and thus the existence of prokaryotic species. However, this assertion might be complicated by the methods used or by the stage of speciation. Models of speciation presented by Polz et al. (2013) and Dvořák et al. (2014b) showed mixed phylogenetic signals based on different loci at the beginning of speciation caused by HGT and HR. A stronger phylogenetic signal comes later during speciation and is balanced until coherent species units are evident (Shapiro et al. 2012). Conversely, Cohan (2011) argues that cohesion is not maintained by barriers of recombination, but rather concerned with ecological diversification, which precedes barriers of recombination (Wiedenbeck and Cohan 2011).

Cohesion might not necessarily be the key factor for the existence of species delimitations, and Kopac et al. (2014) proposed ecological differences among ecotypes as key features. They suggest that ecotypes exist indefinitely, but lineages within ecotypes are changing. In conclusion, regardless mechanisms of coherence, there seem to be coherent evolutionary lineages in cyanobacteria, which might be called species. 


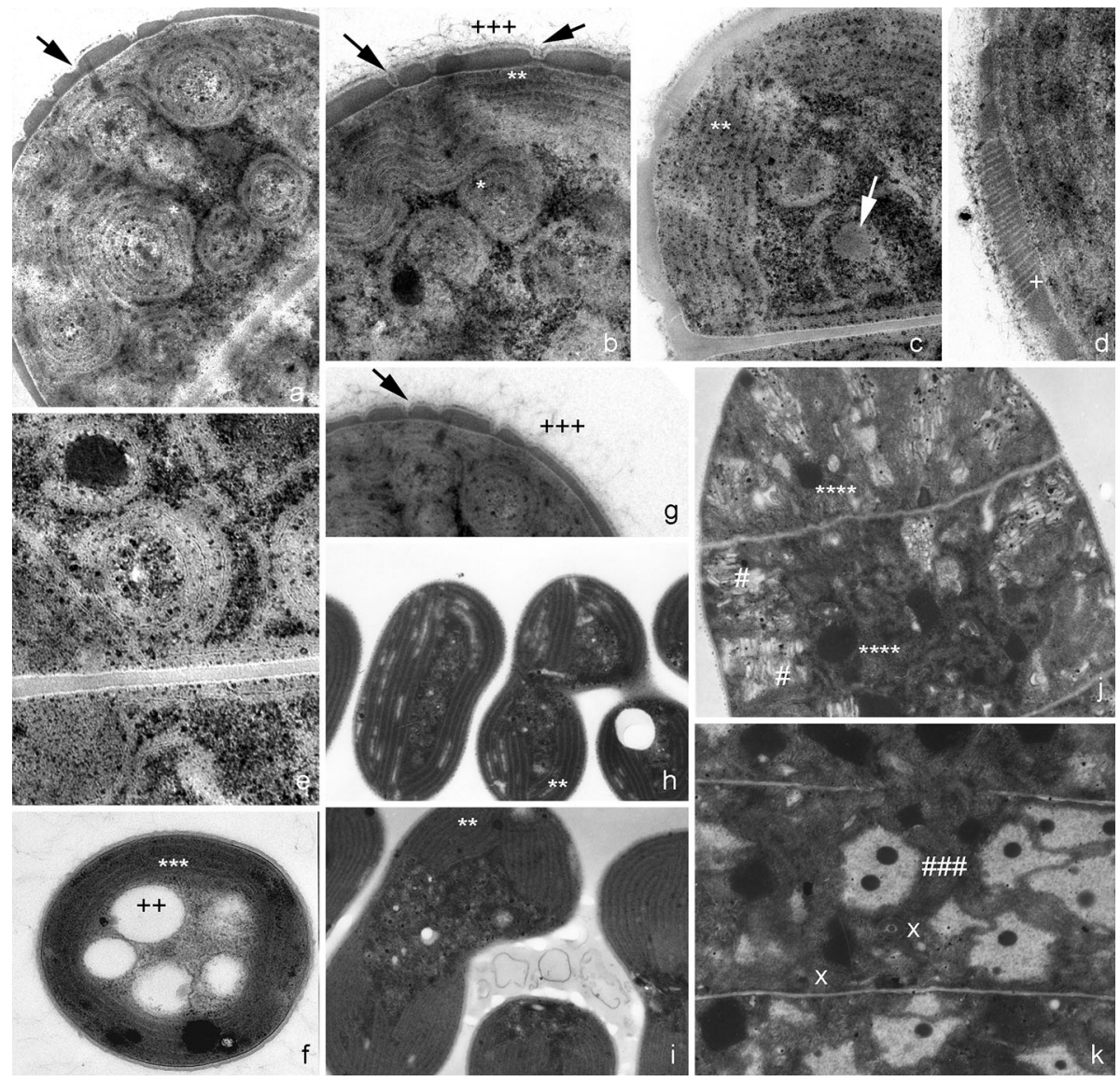

Fig. 2 Transmission electron images of cyanobacteria-illustration of diversity in ultrastructure; a-e, g Hormoscilla pringsheimii; $\mathbf{f}$ Neosynechococcus sphagnicola; $\mathbf{h}$, i Spirulina; $\mathbf{j}, \mathbf{k}$ Arthrospira; a The cell wall depressions (wall pores, black arrows) are the passages through which mucilage crosses the wall. A large part of the cytoplasm is occupied by thylakoids often coiled to form roundish structures formed by circular thylakoids (asterisk) b detail of a. The black arrows indicate the cell wall depressions (mucilage pores). Abundant sheath fibrillar mucilage $(+++)$ is evident along the wall. Some wavy thylakoids $(* *)$ run along the cytoplasmic membrane as single lamellae, while more internally they coil to form roundish bodies (single asterisk). Roundish electron dense bodies (****) represent polyphosphate granules. c Grey spherical bodies (white arrow) in the cytoplasm represent cyanophycin bodies. d Junction pores $(+)$ through the cell wall appear as channels orthogonal to the cytoplasmic membrane surface. e Detail of a polyphosphate granule (****). Many ribosomes can be observed in the cytoplasm, particularly close to the thylakoids. f In unicellular species, thylakoids are typically arranged parietally (***), along the cytoplasmic membrane. Polyhydroxybutyrate bodies (PHB, ++ ) are visible. g Detail of the cell wall depressions (black arrow) and their relationships with the fibrillar component of mucilage. h Image of the spirally arranged filament of Spirulina, whence the frequent observation of double flanked cells. The wavy thylakoids are clustered in bundles of lamellae. i Detail of $\mathbf{h}$. A large part of the cytoplasm is occupied by wavy thylakoids, while the "free" cytoplasm appears lectron dense and containing many different bodies at very variable level of electron density. $\mathbf{j}$ In a filament of Arthrospira the apical cell appears to have a different shape with respect to the other cells. Many heterogeneous cytoplasmic structures are visible, among which polyphosphate bodies (****) and gas vesicles (aerotopes, \#). k Detail of $\mathbf{j}$. Apparently even spaces possibly enclosed by membranes \#\#\# and containing electron dense bodies and fibrillar material can be observed, such bodies are interpreted as assembling carboxysomes. Cylindrical bodies (x) can be observed in the cytoplasm. Material can pass through cell wall pores (microplasmodesmata) from one cell to another in filamentous genera 
Before we begin a discussion of species concepts in bacteria, we would like to emphasize the differences between a species concept and species definition, which is often confused. A species concept is a theoretical demarcation of the species, which would be ideally applicable to all organisms. Conversely, species definitions are a set of rules used for practical identification of species (Hanage 2013). For instance, most bacteriologist use distance among genes or genomes (DNA-DNA hybridization, average nucleotide identity; Richter and Rosselló-Móra 2009) as a species definition while not considering an actual species concept. It does not take into account a phase of speciation or phylogenetic position, and thus it does not show the true evolutionary history of the species.

A possible concept of a bacterial species may be a "genomically and phenomically cohesive cluster" to which a possible concept of species may be applied (Doolittle and Zhaxybayeva 2009). However, the same authors pointed out that there would be "no principled way in which questions about prokaryotic species, such as how many there are, how large their populations are, or how globally they are distributed, can be answered". Thus, the question remains: how to evaluate biodiversity among prokaryotes?

Is there a quantitative threshold of genetic difference sufficient to describe a prokaryotic species in order that eukaryotes-centered biological species concept might work (sensu Mayr 1942, 1946)?

The recognition of the prokaryotic species problem eventually led to a partial consensus about species delimitations (Gevers et al. 2005, 2006; Staley 2006). According to these authors, a prokaryotic species should be recognized primarily on the basis of genotypic similarity and hence mainly on genetic distances. Stakebrandt et al. (2002) proposed that two isolates may be assigned to the same species in case of a value higher than $70 \%$ in a standardized DNA-DNA hybridization experiment. Other distances based on the small subunit (SSU, or 16S) rRNA, could be used to exclude the belonging to the same species in case of a $>97.5 \%$ similarity (Fox et al. 1992; Stackebrandt and Goebel 1994). Another threshold range 98.7-99\% has been proposed by Strackerbrandt and Ebers (2006). Goris et al. (2007), and Richter and Roselló-Móra (2009) proposed 95-96 \% average nucleotide identity (ANI) of homologous genomic regions as a gold standard for species delimitation and also as an alternative to DNA-DNA hybridization. Most recently, Kim et al. (2014) combined previously mentioned approaches and proposed $98.65 \%$ similarity in 16S rRNA as a threshold for species delimitation. Unfortunately, these are all similarity based criteria, and not in line with modern systematics approaches which emphasize broader tools of reconstruction of evolutionary relationships (Castenholz and Norris 2005; Johansen and Casamatta 2005; Komárek 2010 and many others).

The main problem with bacterial species concepts is that they do not fit well into the requirements of the classical species concept used for eukaryotes. Staley (2006) proposed the genomic-phylogenetic species concept, while Achtman and Wagner (2008) adapted the de Queiroz $(2005,2007)$ general lineage concept to a prokaryote-limited metapopulation lineages concept, requiring only that "members" of a species (lineage) evolve separately from other lineages. Such separation would provide the cohesive force that eventually forms a species. However, they observed that such a concept does not provide sufficient detection and quantification of cohesive forces.

One of the main issues in bacterial systematics is whether or not lineages necessarily represent a genetic continuum (Konstantinidis et al. 2006). For example, a simple computational model of randomly replicating lineages will produce groups of genetically related individuals separated by genetic gaps (Zhaxybayeva and Gogarten 2004; Mes 2008; Doolittle and Zhaxybayeva 2009). Hence a "good" species should have deeper gaps with respect to what happens with a random model. The possibility of a failed recognition of 
intermediate forms may also arise due to sampling or difficult cultivability of many bacterial strains, because most bacterial species are unculturable (reviewed in Stewart 2012).

Recent papers have employed multi-locus DNA sequences analyses (MLSA) for species definition, which often yield results that fit with traditionally delimited species (Gevers et al. 2005; Hanage et al. 2005, 2006). MLSA has been developed originally for identification of pathogenic strains of bacteria due to lack of resolution of traditional genetic markers, mainly the 16S rRNA gene (Maiden et al. 1998). For example, Melendrez et al. (2011) used three protein coding genes and found 4-14 times more ecotypes in the thermophilic Synechococcus sp. inhabiting Mushroom Spring in Yellowstone National Park than based solely on 16S rRNA and 16S-23S ITS sequence. Thus MLSA provides significantly higher resolution. Similar considerations may be obtained from the investigations on the marine planktic genera Synechococcus and Prochlorococcus (Johnson et al. 2006) or fine-scale distribution of marine Vibrionaceae (Preheim et al. 2011). On the other hand, Kopac et al. (2014) analyzed all orthologous genes within Bacillus subtilis and showed that MLSA was insufficient to distinguish ecotypes, which are considered as species in this paper.

Recently, DNA barcoding has been proposed as a possibility for cyanobacteria. Eckert et al. (2015) tested barcoding gaps in cyanobacteria and found that barcoding gaps among species were identified in a half of investigated cases. Thus, this approach has to be further investigated before it takes place in practical identification of species.

\section{Speciation factors in (cyano)bacteria}

Bacteria and Archaea are evolutionarily intriguing as they are asexual, and possess extensive populations with relatively short generation times (for review see Cohan 2001, 2002). Cohesive or disruptive forces shaping bacterial species have remained enigmatic for a long time. However, the development of modern molecular methods has shown significant differences between prokaryotic and eukaryotic evolutionary trajectories. For example, some of the non-consistent phylogenetic signals of different gene families within the same bacterial species have been explained by HGT and HR (e.g. Hanage et al. 2005; Lodders et al. 2005; David and Alm 2011). It has been suggested that a part of the bacterial genome usually referred to as the core genome is more stable with less evolutionary changes. The core genome is usually defined as a portion of genes shared by some group of bacteria coding for essential metabolic pathways (Daubin et al. 2002; Shi and Falkowski 2008; Polz et al. 2013). The shell or flexible genome refers to a less stable part of bacterial genome which undergoes substantial evolutionary changes including HGT (Hess 2011). It often contains genes specific to some environment with a large portion of unannotated gene families without any known function (e.g. Shi and Falkowski 2008), which putatively plays an important role in rapidly changing environments (Rodriguez-Valera et al. 2009) and niche partitioning among close relatives (Kopac et al. 2014). The shell genome genes do not seem to be randomly dispersed over the chromosome, but rather concentrated within genomic islands with frequent HGT and HR events (Hacker and Carniel 2001; RodriguezValera et al. 2009). However, Narechania et al. (2012) showed that many core genes have an identical phylogenetic signal as shell genes, which denotes their common evolutionary history. Narechania et al. (2012) defined core genome as orthologs with the same phylogenetic tree topology and the shell genome as composed of the rest of orthologs. Core genes may also exhibit evidence of HGT events, which might be identified by comparing scenarios of gene phylogenies with individual species trees (David and Alm 2011; Nakhleh 
2013). The question remains, though, do these changes provide enough force to diverge evolutionary lineages with subsequent cohesion to form an analogue of the eukaryotic "sexual" species?

The most extensively studied HGT events are concerned with the human microbiome (e.g. Smillie et al. 2011) and marine picoplankton, mostly of the genera Synechococcus and Prochlorococcus (e.g. Marston et al. 2012). In terms of cyanobacteria, it has been further suggested that most HGT are mediated by phages (cyanophages) (e.g. Sullivan et al. 2010; Sabehi et al. 2012). These phages often contain genes important in photosynthesis (Zheng et al. 2014). While HGT events may occur between phylogenetically divergent lineages, they are most frequent among individual species within the same environment and decrease with the overall genetic distance of genomes (Popa et al. 2011). A very similar phenomenon has been observed in HR (Smillie et al. 2011). Fraser et al. (2007) modeled HR within bacteria, showing that if HR exceeds mutation rate, a species evolves in a similar manner as sexually reproducing eukaryotes, and with low HR the populations are clonal. Polz et al. (2013) suggested in their synthesis that rather than genetic isolation of emerging lineages, there exist local genetic innovative gene pools (i.e. local metagenomes), which are constantly changing by HGT within a pool and by input of incoming genotypes.

Besides genetic isolation resulting from genome differentiation, which takes place in population without geographical isolation (sympatric speciation) often observed in bacteria (e.g. Friedman et al. 2013; Koeppel et al. 2013), there are geographical and ecological factors affecting bacterial speciation. The speciation of macroorganisms is often driven by geographical isolation (allopatry) due to their limited dispersal capabilities. This has also been in, e.g., asexual rotifers, but on a larger geographical scale (Fontaneto et al. 2008). However, how these processes relate to microorganisms is still subject to broad debate (see Martiny et al. 2006; Ramette and Tiedje 2007 for review). Baas Becking (1934) postulated that all microbes can spread everywhere and only the specific local environmental conditions would select actual species composition. However, recent analyses of different molecular markers reveal an ambiguous signal. For example, thermophilic cyanobacteria Mastigocladus laminosus and Synechococcus spp. showed geographical difference based on 16S rRNA analysis (Papke et al. 2003; Miller et al. 2007). However, it should be noted that in the case of Synechococcus (Papke et al. 2003), the clusters were genetically very distant, which might be because they belong to different taxa (even genera) and there is not sufficient variation within a species to elucidate meaningful patterns. Dvořák et al. (2012) showed that episodic genetic isolation of the mat-forming cyanobacterium Microcoleus vaginatus may have led to the speciation events. On the other hand, 16S-23S ITS phylogenies of the freshwater, planktic cyanobacterium Microcystis aeruginosa revealed no connection between geographic position and a placement in phylogeny (van Gremberghe et al. 2011). Further, no geographical patterning has been observed in polar cyanobacteria based on 16S rRNA (Jungblut et al. 2010). Taken together, the role of geographical isolation as it relates to the speciation of microbes should be further investigated using whole genome data or using more variable genome regions (Ramette and Tiedje 2007). A whole genome approach has been used in thermophilic archeon Sulfolobus islandicus, which has shown clear geographical patterning (Reno et al. 2009). This may reveal very recent events of genetic exchange leading to speciation as in case of marine picoplanktic Synechococcus (e.g. Mazard et al. 2012) because the geographical isolation may be important in a very short time frame (Ramette and Tiedje 2007; Dvořák et al. 2012) rather than in relatively long times as observed in macroorganisms. 
Cohan (2001) advocates a bacterial speciation model by ecological diversification. When a new niche is introduced the stable ecotype is periodically overgrown by new, "fitter" ecotypes, which are able to effectively exploit the new niche. Periodic selection events decrease the overall genetic diversity and after some time a new ecotype can be sufficiently diversified to form a new stable ecotype, which may be non-competing with the parental genotype. This also results with the coherence within evolutionary linages.

The ecotype model of prokaryotic speciation proposed by Cohan $(2001,2002,2006)$ and Cohan and Perry (2007) treat bacteria as asexual clones, where homologous recombination rates are low. Thus, many crucial questions still remain as unanswered concerning the mechanism of bacterial speciation.

\section{Particular problems of species definitions and concepts in cyanobacteria}

The previously mentioned concepts and definitions of species are also applicable to cyanobacteria, but in the following paragraphs, we will emphasize some important considerations pertaining to cyanobacteria.

A classic, phenetic species concept using only morphological or ecological data has been shown to be insufficient to describe the real biodiversity within cyanobacteria. Morphology alone in cyanobacteria often lacks resolution on the species level, while completely ignoring cryptic species (e.g. Johansen and Casamatta 2005; Hašler et al. 2012, and many others, see further). Cyanobacterial species have traditionally been distinguished based on the similarity of morphological markers, which might be very subjective. Moreover, some morphological characters, such as sheath formation or presence of heterocytes, may be lost in cultures and environmentally plastic. For example, Microcoleus vaginatus, which is usually found in soil crusts, puddles and other aerophytic habitats, has multiple filaments enclosed in common sheath. However, strains isolated from epipelon (fine lake sediment) produce no sheath in nature or culture. An analysis of morphology, $16 \mathrm{~S}$ rRNA-based phylogeny and 16S-23S ITS secondary structure revealed very close relations with soil crust $M$. vaginatus strains (Hašler et al. 2012). 16S rRNA of all strains also contained an $11 \mathrm{bp}$ insert typical for this species (Boyer et al. 2002). Phenotypic characters (i.e. cell dimension, division type, color) provided insufficient resolution for discerning these lineages. The employment of new characters (mostly 16S-23S ITS region) have allowed researchers to recognize finer differences among taxa with coherent morphology, leading to the idea of cryptic speciation (Boyer et al. 2001; Siegesmund et al. 2008; Komárek 2010, 2011; Hašler et al. 2012). Cryptic taxa are unrecognizable using solely morphological characters. Cryptic species have been identified or suggested in almost all traditional genera (Komárek 2010) such as with the mat-forming cyanobacteria Microcoleus (Siegesmund et al. 2008), Oculatella (Osorio-Santos et al. 2014), Trichocoleus (Mühlsteinová et al. 2014) and Phormidium (Casamatta et al. 2003; Hašler et al. 2012). This topic is discussed in great extent elsewhere (e.g. Johansen and Casamatta 2005; Komárek 2010). It should be noted that genus Oculatella consists of 7 cryptic species (Osorio-Santos et al. 2014), which were able to be resolved based on 16S-23S ITS sequence, which has higher resolution under the genus level.

A majority of recent taxonomic revisions and descriptions use a combination of morphological, ecological, and genetic observations, referred to as a polyphasic approach (Castenholz 1992; Castenholz and Norris 2005; Komárek 2003, 2010; Komárek et al. 2014). It has already been employed to recognize separate evolutionary lineages and for description of new species. A polyphasic approach is commonly used in taxonomic works 
in combination with a monophyletic species concept sensu Johansen and Casamatta (2005), if phylogenetic analyses of 16S rRNA or other genes are used.

$16 \mathrm{~S}$ rRNA sequencing and progress in phylogenetic reconstruction have allowed researchers to employ the evolutionary species concept sensu Simpson (1953). This has facilitated further derived species concepts like the monophyletic species concept. Johansen and Casamatta (2005) used this to define a species as the smallest monophyletic group with recognizable autapomorphy (a trait unique only for particular taxon). They also designed a concrete species definition based on the mentioned concept, which is suitable for cyanobacteria and may be used under the International Code of Botanical Nomenclature. It is probably the most widely accepted concept with cyanobacteria (according to the number of taxonomic papers using the concept under the Botanical Code), although sometimes not precisely followed (Siegesmund et al. 2008; Perkerson et al. 2011; Dvořák et al. 2014a; Hašler et al. 2012, 2014a, b; Osorio-Santos et al. 2014 and many others). The most important advantage of the monophyletic species concept is the general applicability to asexual organisms. However, it might be problematic when a monophyletic lineage lacks sufficient morphological, ecological or physiological differentiation. Moreover, monophyletic species concept is not accepted in the International Code for Nomenclature of Bacteria, which uses species concepts mentioned above.

Synechococcus sensu lato is a group of cyanobacteria with cosmopolitan distribution inhabiting almost all environments (Komárek and Anagnostidis 1998), including thermal and aerophytic habitats (Honda et al. 1999; Robertson et al. 2001). Although some cyanobacteria, such as Synechococcus sensu lato, lack phenotypic variability, great ecological and genetic diversity suggest that polyphyletic complexes of cryptic taxa might exist (Honda et al. 1999; Robertson et al. 2001; Dvořák et al. 2014a, b). Many traditional cyanobacterial genera (Geitler 1932) are polyphyletic (Komárek 2010; Engene et al. 2011; Hašler et al. 2012; Engene et al. 2013; Dvořák et al. 2014a, b; Hašler et al. 2014a) and need extensive revisions, which will be very difficult particularly in the case of Synehococcus sensu lato due to extreme polyphyly within this genus. We suggest that this extreme polyphyly (cryptogenera sensu Komárek et al. 2014) should be distinguished from polyphyly in the original sense, since in extreme polyphyly a large number of lineages derived over very long time period (over 3 billion years), as shown in Dvořák et al. (2014b).

Such extreme polyphyletic groups with little morphological distinction, in which similar morphotypes may belong to polyphyletic lineages and hence different genera, suggest that taxonomic revisions based solely on morphological data must be performed with great caution. Thus, stable molecular markers such as $16 \mathrm{~S}$ rRNA should be used for taxonomic revisions (see Komárek 2010 for a review). However, even revisions of genera without molecular support for all studied species have been recently proposed. For instance, after recent revisions of polyphyletic genera with molecular markers, some authors have added new species based on morphological similarity as new combinations (Strunecký et al. 2014). However, these species might be polyphyletic taxa in a manner similar to Synechococcus. Therefore, we recommend the use of molecular data in all cases to increase the certainty of taxonomic revisions.

A growing number of polyphyletic genera recently identified might be connected with frequent convergent evolutionary events in cyanobacteria. Convergent evolution is a phenomenon that occurs when similar features have evolved in independent lineages. It seems to be very frequent in cyanobacteria and is evidenced by several phenotypic traits (e.g. Shishido et al. 2013; Dvořák et al. 2014b). We have chosen the example of the prochlorophytes to show another case of convergence in cyanobacteria. 
Prochlorococcus, Prochlorothrix, and Prochloron are cyanobacteria that additionally produce chlorophyll $b$ (the typical pigment of green algae and land plants) and lack phycobilisomes (Giddings et al. 1980; Burger-Wiersma et al. 1986; Miller et al. 1988; Chisholm et al. 1992; Hess et al. 1996; Pinevich et al. 1997; Kauff and Büdel 2011). On this basis and due to a psbA gene based phylogenetic analysis, they were considered strictly associated with the chloroplast of green algae and terrestrial plants (Morden and Golden 1989). Successive analyses (e.g., Litvaitis 2002) showed that prochlorophytes actually nested within cyanobacteria, and are polyphyletic. The conclusion is that the appearance of chlorophyll $b$ and the loss of phycobilisomes evolved multiple times in different lineages, and hence these characters are subjected to convergent evolution and reversals, probably in connection to environmental pressures.

We note that Prochlorococcus marinus appears to cluster quite clearly apart from the other cyanobacteria on the basis of the analysis of all the tRNA sequences, considering the isoacceptor variation for each codon and the number of copies for each type of tRNA (Fig. 3). This suggests convergent or parallel evolutionary events leading to similar phenotypic traits, because it contradicts phylogenomic analyses in Shih et al. (2013). Such convergent events might be explained by HGT within the environment and therefore environmental pressures (Litvaitis 2002). It is also likely that it represents a frequent trend in cyanobacterial evolution, since other morphological traits, such as multicellularity, have evolved repeatedly (Honda et al. 1999; Robertson et al. 2001; Schirrmeister et al. 2013; Dvořák et al. 2014a, b). Dvořák et al. (2014b, Fig. 4) also suggested a model of serial convergence in cyanobacteria, where frequent convergent events might be explained by constant genetic changes via HGT and HR within local habitat gene pools as proposed by Polz et al. (2013).

\section{Diversity of cyanobacteria and their current classification}

Taxonomy is usually defined as an operative version of systematics. Both the taxonomy and systematics of cyanobacteria have undergone substantial changes in the last two

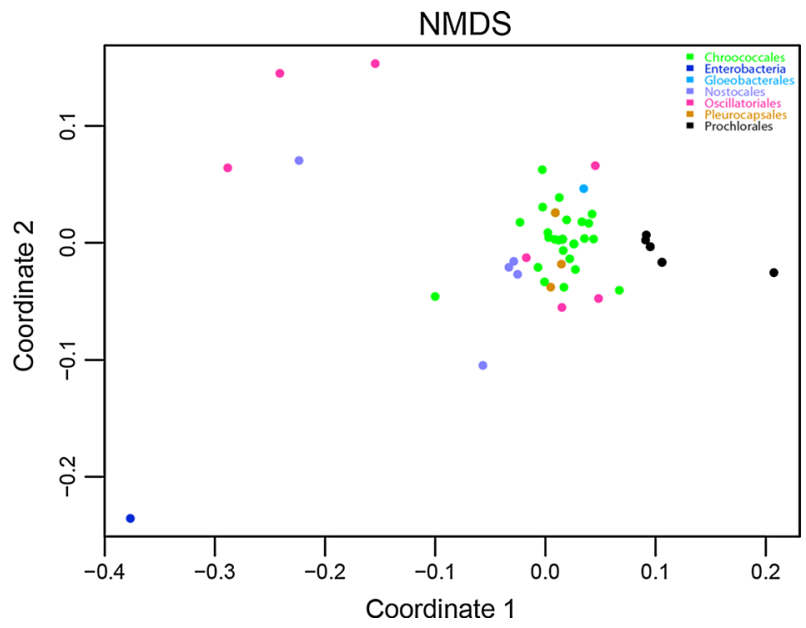

Fig. 3 Plot derived from MDS analysis representing the diversity of cyanobacterial strains and lineages on the basis of variation in tRNA isoacceptors (tRNA targeting considering also different tRNAs but with the same anticodon) for each amino acids types and copy number calculated on the known complete genomes of cyanobacteria. Only 5 of 9 accessions of prochlorophytes are visible, since 4 accessions are completely overlapping with the others. (Color figure online) 
decades. Previously, the cyanobacteria were placed into three botanical orders, the number of which has changed with respect to the state of investigation of morphological variability and ecology of the species. Geitler (1932) revised the systematics of cyanobacteria established in the nineteenth century and proposed three orders: Chroococcales (coccoidal species reproducing by binary fission), Chamaesiphonales (a heteropolar type of binary fission), and Hormogonales (the filamentous species). Other authors of the twentieth century usually followed Geitlers botanical system. However, their systems changed as additional characters were uncovered and additional taxa included, e.g. Desikachary (1959) distinguished five orders (Chroococcales, Chamaesiphonales, Pleurocapsales, Nostocales, and Stigonematales), and Starmach (1966) split the system of cyanobacteria into four classes (Chroococcophyceae, Chamaesiphonophyceae, Pleuastrophyceae, and Hormogoniophyceae).

Later, in the 1970s, a bacteriological approach was used in the classification of cyanobacteria (Stanier et al. 1978). Five subgroups, corresponding to the orders Chroococcales, Pleurocapsales, Oscillatoriales, Nostocales, and Stigonematales, were classified with respect to the type of cell reproduction, cell differentiation, and molecular/ biochemical attributes (Rippka et al. 1979; Boone and Castenholz 2001). This classification concept facilitated substantial progress in the research on cyanobacteria because of the new methods advocated.

The most comprehensive studies on the classification of cyanobacteria in the modern era were made by Anagnostidis and Komárek (1985, 1988, 1990; Komárek and Anagnostidis 1986, 1989). The authors combined both botanical and bacteriological approaches, integrating traditional cyanobacterial morphology, physiology, and ecology in a total evidence synthesis. They established four orders: Chroococcales (non-filamentous), Oscillatoriales (filamentous, lacking specialized cells), Nostocales (filamentous, facultative specialized cells), and Stigonematales (filamentous, obligatory specialized cells, and division in multiple planes). During the 1990s, analysis of the 16S rDNA gene elucidated and supported phylogenetic relationships among morphologically similar genera, and, surprisingly, among genera from different orders as defined by Anagnostidis and Komárek. Hoffmann et al. (2005) proposed a new system of classification where members of the Chroococcales and Oscillatoriales formed two subclasses, the Synechococcophycideae and the Oscillariophycidae. Members of the Nostocales and Stigonematales belonged to a separate monophyletic subclass, the Nostochophycideae. Terminal taxonomic units (genera and species) represent a crucial element in the world of cyanobacteria. Numerous new genera are being erected because molecular methods usually show a higher diversity than the traditional botanical (morphological) approach by providing additional character sets (cryptic species). This topic is discussed in greater extent above. This system of higher taxonomic ranks has been recently re-evaluated in a review by Komárek et al. (2014). These authors proposed a subdivision of cyanobacteria based on phylogeny and morphology in the following orders: Gloeobacterales, Synechococcales, Spirulinales, Pleurocapsales, Chroococcales, Chroococcidiopsidales, Oscillatoriales, and Nostocales.

The higher level systematic classification of cyanobacteria needs more investigation based on revised genera. A complete revision should include morphological description of natural populations based on light and electron microscopy, habitat characterization, molecular analysis of $16 \mathrm{~S}$ rRNA gene and other markers such as ITS region and information about stored strains or DNA. Moreover, important consideration should be given to biochemical/bioorganic data, e.g. fatty acids composition of cyanobacterial cell wall, which seems to be applicable for species identification (Caudales et al. 2000; Rezanka et al. 2003; Li and Watanabe 2004). 
Whenever a wide agreement on species concepts in cyanobacteria is reached, some practical identification of species and other taxa open another ample array of problems. For instance, cyanobacteria may be described under both the International Code for Algae, Fungi and Plants (ICN, http://www.iapt-taxon.org/nomen/main.php) and the International Code for Nomenclature of Prokaryotes (ICNP), although the vast majority of cyanobacterial taxa are described under the Botanical Code (Oren 2011). The reason for that are the strict requirements of the ICNP, i.e. axenic culture and DNA-DNA hybridization etc. Detailed values, description and discussion may be found on the website of the International Committee on Systematics of Prokaryotes (http://icsp.org/; Starkerbrandt et al. 2002; Oren and Garrity 2014). Some additional problems in the application of the ICNP to cyanobacteria are discussed in Oren (2004, 2011), and Oren and Tindall (2005). An attempt to develop a special code valid only for cyanobacteria has been proposed at the Meeting of the International Association for Cyanophyte Research in Luxembourg in 2004 (http://www.cyanodb.cz/files/CyanoGuide.pdf). However, it is an unofficial document that has not yet been accepted. Thus, a schism among cyanobacteriologists still continues, but a number of authors largely favor the Botanical Code, because new taxa might be described without cultures (e.g. Hašler et al. 2014a).

\section{Estimate of the total cyanobacterial biodiversity}

Culture-independent estimates of prokaryotic biodiversity fall between millions and billions of species (e.g., Dykhuizen 1998; Gans et al. 2005). Estimates of the current cyanobacterial biodiversity range from 2000 (Sant́Anna et al. 2006) to 8000 (Guiry 2012). Nabout et al. (2013) applied a discovery curve to cyanobacteria utilizing the CyanoDB database (http://www.cyanodb.cz/) with three asymptotic models, yielding from 3166 to 6280 species, depending on the model of choice. A total of 453 authors have described cyanobacterial taxa, and two of them (J. Komárek and K. Anagnostidis) have described $30.9 \%$ of the total described species (Nabout et al. 2013). However, the real number of species can be barely assessed by statistics. It requires extensive observation of the species diversity and distribution in nature (Foissner 2006) with subsequent quantification. In the future, genetic and molecular data will be increasingly helpful. For example, the last decade of polyphasic studies brought tens of newly erected or revised cyanobacterial genera (e.g. see Komárek 2010 for review of older works, afterwards e.g. Strunecký et al. 2011; Komárek et al. 2013; Komárková et al. 2013; Dvořák et al. 2014a). During the 19th Symposium of the International Society for Cyanophyte Research in 2013, 16 new genera were presented (Komárek et al. 2014). Thus, the great atomization of cyanobacterial systematics is now in progress, which is a result of species definition, concept used, and introduction of molecular methods into cyanobacterial systematics. Moreover, with higher resolution abilities, we can expect a further expansion of the number of described taxa. For example, Oculatella erected with single species (Zammit et al. 2012) now contains seven species, which have been described by different researchers. Thus, even the most liberal estimates may be undervalued.

\section{Conclusions and future directions}

Great challenges lie ahead in regards to the taxonomy and systematics of cyanobacteria. Fortunately, molecular techniques have facilitated a renaissance in describing and 
elucidating cyanobacterial biodiversity. In this review, we showed that although cyanobacteria lack sexual reproduction, we are able to apply, in terms of evolutionarylineage coherence, a species concept similar to that one used for eukaryotic macroorganisms, even though it might be considered "fuzzy" due to the molecular markers applied, homologous recombination or horizontal gene transfer. However, many questions remain regarding cyanobacterial species definitions and concepts. Caution must be maintained, though, as morphology is sometimes in conflict with molecular markers, or has limited resolution. Therefore, cryptic species and extremely polyphyletic genera caused by serial convergence represent problematic phenomena resulting with uncertainty of proper morphological identification. We suggest that more attention should be paid to the use of molecular markers in taxonomy and practical identification of taxa. On the other hand, ecological and morphological criteria are also important, which should be taken into consideration. Thus, deposited sequences in GenBank and other databases should also be completed with such data or they should be made easily accessible by providing the original papers. These data may be afterwards a source for a barcoding database, which would provide correct and fast identification workflow, and would resolve cryptic taxa and polyphyletic genera problems.

The rapidly growing number of described taxa signifies large gaps in our current knowledge of cyanobacterial biodiversity and distribution. Although the total biodiversity of any microbial lineage is probably unknown, all estimations suggest a significant increase of described taxa. Moreover, the selected species definition will impact on how many species are identified and will be recognized in the future. It also largely influences possible patterns of distribution. Thus, evidently, we are now in a period of important changes in taxonomy, and knowledge of cyanobacterial biodiversity is amplified by novel techniques, and increasing sampling effort.

\section{Methods of analysis}

Multivariate statistics have been carried out by using the R software 3.0 (R Development Core Team 2013) and some functions included in Vegan and MASS packages (Venables and Ripley 2002; Oksanen et al. 2013). Transfer RNA data of all the analyzed organisms have been imported in $\mathrm{R}$ as dataframe. The distance matrix has been computed using the "vegdist" function and selecting "jaccard" as method. The quantitative form of the Jaccard distance in Vegan actually is the Ruzicka index and has been preferred over the Euclidean distance for its better performances in presence of species containing missing tRNA (counts equal to zero). In order to visualize the distances between organisms, data have been statistically explored through unconstrained ordination by computing a nonmetric multidimensional scaling (NMDS) using the "metaMDS" function included in the Vegan package. Multidimensional Scaling helps to visualize the distance between samples through a low-dimensional spatial map. The non-metric scaling methods are able to map non-Euclidean distances.

Acknowledgments This study was funded by following projects: ESF Post-UP II CZ.1.07/2.3.00/30.0041 and Internal Grant agency of Palacký University Prf-2014001 and Prf-2015-001. Moreover, we would like to express our gratitude to the anonymous reviewers, who helped to improve the text especially from viewpoint of the Bacteriological Code. 
Open Access This article is distributed under the terms of the Creative Commons Attribution License which permits any use, distribution, and reproduction in any medium, provided the original author(s) and the source are credited.

\section{References}

Achtman M, Wagner M (2008) Microbial diversity and the genetic nature of microbial species. Nat Rev Microbiol 6:431-440

Anagnostidis K, Komárek J (1985) Modern approach to the classification system of cyanophytes 1-introduction. Algol Stud 38(39):291-302

Anagnostidis K, Komárek J (1988) Modern approach to the classification system of cyanophytes 3-Oscillatoriales. Algol Stud 50-53:327-472

Anagnostidis K, Komárek J (1990) Modern approach to the classification system of cyanophytes 5-Stigonematales. Algol Stud 59:1-73

Baas Becking LGM (1934) Geobiologie of inleiding tot de miliekunde. W. P. van Stockum, The Hague

Bekker A, Holland HD, Wang P-L et al (2004) Dating the rise of atmospheric oxygen. Nature 427:117-120

Boone, Castenholz RW (2001) Bergey's manual of systematic bacteriology volume 1: the Archaea and the Deeply branching and phototrophic Bacteria. Springer, New York

Boyer SL, Fletchner V, Johansen JR (2001) Is the 16S-23S rRNA internal transcribed spacer (ITS) region a good tool for use in molecular systematics and population genetics? A case study in cyanobacteria. Mol Biol Evol 18:1057-1069

Boyer SL, Johansen JR, Howard GL (2002) Phylogeny and genetic variance in terrestrial Microcoleus (Cyanophyceae) species based on sequence analysis of the 16S rRNA gene and associated 16S-23S ITS region. J Phycol 38:1222-1225

Burger-Wiersma T, Veenhuis M, Korthals HJ, Van de Wiel CCM, Mur LR (1986) A new prokaryote containing chlorophylls $a$ and $b$. Nature 320:262-264

Casamatta DA, Vis ML, Sheath RG (2003) Cryptic species in cyanobacterial systematics: a case study of Phormidium retzii (Oscillatoriales) using 16S rDNA and RAPD analyses. Aquat Bot 77:295-309

Castenholz RW (1992) Species usage, concept, and evolution in the cyanobacteria (blue-green algae). J Phycol 28:737-745

Castenholz RW, Norris TB (2005) Revisionary concepts of species in the Cyanobacteria and their applications. Algol Stud 117:53-56

Caudales R, Wells JM, Butterfield JE (2000) Cellular fatty acid composition of cyanobacteria assigned to subsection II, order Pleurocapsales. Int J Syst Evol Microbiol 50:1029-1034

Chisholm SW, Frankel SL, Goericke R, Olson RJ, Palenik B, Waterbury JB, West-Johnsrud L, Zettler ER (1992) Prochlorococcus marinus gen. nov.: an oxyphototrophic marine prokaryote containing divinyl chlorophyll $a$ and $b$. Arch Microbiol 157:297-300

Cohan FM (2001) Bacterial species and speciation. Syst Biol 50:513-524

Cohan FM (2002) What are bacterial species? Annu Rev Microbiol 56:457-487

Cohan FM (2006) Towards a conceptual and operational union of bacterial systematics, ecology, and evolution. Philos Trans R Soc Lond B Biol Sci 361:1985-1996

Cohan FM (2011) Are species cohesive? A view from bacteriology. In: Walk ST, Feng PCH (eds) Population genetics of bacteria: a tribute to Thomas S. Whittam, ASM Press, Washington DC

Cohan FM, Perry EB (2007) A systematics for discovering the fundamental units of bacterial diversity. Curr Biol 17:R373-R386

Daubin V, Gouy M, Perriere G (2002) A phylogenomic approach to bacterial phylogeny: evidence of a core of genes sharing a common history. Genome Res 12:1080-1090

David LA, Alm EJ (2011) Rapid evolutionary innovation during an Archean genetic expansion. Nature 469:93-96

de Queiroz K (2005) Ernst Mayr and the modern concept of species. Proc Natl Acad Sci USA 102:6600-6607

de Queiroz K (2007) Species concepts and species delimitation. Syst Biol 56:879-886

Desikachary TV (1959) Cyanophyta. In: Randhawa MS (ed) I.C.A.R. monographs on algae. Indian Council of Agriculture Research, New Dehli

Doolittle WF, Zhaxybayeva O (2009) On the origin of prokaryotic species. Genome Res 19:744-756

Dvořák P, Hašler P, Poulíčková A (2012) Phylogeography of the Microcoleus vaginatus (cyanobacteria) from three continents-a spatial and temporal characterization. PLoS One 7:e40153. doi:10.1371/ journal.pone.0040153 
Dvořák P, Casamatta DA, Hašler P, Ondřej V, Poulíčková A, Sanges R (2014a) Synechococcus: 3 billion years of global dominance. Mol Ecol 23:5538-5551

Dvořák P, Hindák F, Hašler P, Hindáková A, Poulíčková A (2014b) Morphological and molecular studies of Neosynechococcus sphagnicola, gen. et sp. nov. (Cyanobacteria, Chroococcales). Phytotaxa 170:24-34

Dykhuizen DE (1998) Santa Rosalia revisited: why are there so many species of bacteria? Antonie Van Leeuwenhoek 73:25-33

Eckert EM, Fontaneto D, Coci M, Callieri C (2015) Does a barcoding gap exist in prokaryotes? Evidences from species delimitation in cyanobacteria. Life 5:50-64

Engene N, Choi H, Esquenazi E, Rottacker EC, Ellisman MH, Dorrestein PC, Gerwick WH (2011) Underestimated biodiversity as a major explanation for the perceived prolific secondary metabolite capacity of the cyanobacterial genus Lyngbya. Environ Microbiol 13:1601-1610

Engene N, Gunasekera SP, Gerwick WH, Paul VJ (2013) Phylogenetic inferences reveal large extent of novel biodiversityin chemically rich tropical marine cyanobacteria. Appl Environ Microbiol 79:1882-1888

Foissner W (2006) Biogeography and dispersal of micro-organisms: a review emphasizing protists. Acta Protozool 45:111-136

Fontaneto D, Barraclough TG, Chen K, Ricci C, Herniou EA (2008) Molecular evidence for broad-scale distribution in bdelloid rotifers: everything is not everywhere but most things are very widespread. Mol Ecol 17:3136-3146

Fox GE, Wisotzkey JD, Jurtshuk P Jr (1992) How close is close: 16S rRNA sequence identity may not be sufficient to guarantee species identity. Int J Syst Bacteriol 42:166-170

Fraser C, Hanage WP, Spratt BG (2007) Recombination and the nature of bacterial speciation. Science 315:476-480

Friedman J, Alm EJ, Shapiro BJ (2013) Sympatric speciation: when is it possible in bacteria? PLoS One 8:e53539

Gans J, Wolinsky M, Dunbar J (2005) Computational improvements reveal great bactgerial diversity and high metal toxicity in soil. Science 309:1387-1390

Geitler L (1932) Cyanophyceae. In: Rabenhorst L (ed) Kryptogamenflora. Akademische Verlagsgesellschaft, Leipzig

Gevers D, Cohan FM, Lawrence JG et al (2005) Opinion: re-evaluating prokaryotic species. Nat Rev Microbiol 3:733-739

Gevers D, Dawyndt P, Vandamme P, Willems A, Vancanneyt M, Swings J, De Vos P (2006) Stepping stones towards a new prokaryotic taxonomy. Philos Trans R Soc Lond B Biol Sci 361:1911-1916

Giddings TH, Withers NW, Staehelin LA (1980) Supramolecular structure of stacked and unstacked regions of the photosynthetic membranes of Prochloron sp., a prokaryote. Proc Natl Acad Sci USA $77: 352-356$

Goris J, Konstantinidis JT, Klappenbach JA, Coenye T, Vandamme P, Tiedje JM (2007) DNA-DNA hybridization values and their relationship to whole-genome sequence similarities. Int $\mathbf{J}$ Syst Evol Microbiol 57:81-91

Guiry MD (2012) How many species of algae are there? J Phycol 48:1057-1063

Hacker J, Carniel E (2001) Ecological fitness, genomic islands and bacterial pathogenicity-a Darwinian view of the evolution of microbes. EMBO Rep 2:376-381

Hanage WP (2013) Fuzzy species revisited. BMC Biol 11:41

Hanage WP, Fraser C, Spratt BG (2005) Fuzzy species among recombinogenic bacteria. BMC Biol 3:6

Hanage WP, Fraser C, Spratt BG (2006) Sequences, sequence clusters and bacterial species. Philos Trans R Soc Lond B Biol Sci 361:1917-1927

Hašler P, Dvořák P, Johansen JR, Kitner M, Ondřej V, Poulíčková A (2012) Morphological and molecular study of epipelic filamentous genera Phormidium, Microcoleus and Geitlerinema (Oscillatoriales, Cyanophyta/Cyanobacteria). Fottea 12:341-356

Hašler P, Dvořák P, Poulíčková P (2014a) A new genus of filamentous epipelic cyanobacteria, Johansenia. Preslia 86:81-94

Hašler P, Dvořák P, Poulíčková P, Casamatta DA (2014b) A novel genus Ammassolinea gen. nov. (Cyanobacteria) isolated from sub-tropical epipelic habitats. Fottea 14:241-248

Hess WR (2011) Cyanobacterial genomics for ecology and biotechnology. Curr Opin Microbiol 14:608-614

Hess WR, Partensky F, van der Staay GWM, Garcia-Fernandez JM, Borner T, Vaulot D (1996) Coexistence of phycoerythrin and a chlorophyll $a / b$ antenna in a marine prokaryote. Proc Natl Acad Sci USA 93:11126-11130

Hoffmann L, Komárek J, Kaštovský J (2005) System of Cyanoprokaryotes (cyanobacteria) state in 2004. Algol Stud 117:95-115 
Honda D, Yokota A, Sugiyama J (1999) Detection of seven major evolutionary lineages in cyanobacteria based on the 16S rRNA gene sequence analysis with new sequences of five marine Synechococcus strains. J Mol Evol 48:723-739

Johansen JR, Casamatta DA (2005) Recognizing cyanobacterial diversity through adoption of a new species paradigm. Algol Stud 117:71-93

Johnson ZI, Zinse ER, Coe A, McNulty NP, Woodward EMS, Chisholm SW (2006) Niche partitioning among Prochlorococcus ecotypes along ocean-scale environmental gradients. Science 311:1737-1740

Jungblut AD, Lovejoy C, Vincent WF (2010) Global distribution of cyanobacterial ecotypes in the cold biosphere. ISME J 4:191-202

Kauff F, Büdel B (2011) Phylogeny of cyanobacteria: an overview. Prog Bot 72:209-224

Kim M, Oh HS, Park SC, Chun J (2014) Towards a taxonomic coherence between average nucleotide identity and 16S rRNA gene sequence similarty for species demarcation of prokaryotes. Int J Syst Evol Microbiol 64:346-351

Koeppel AF, Wertheim JO, Barone L, Gentile N, Krizanc D, Cohan FM (2013) Speedy speciation in bacterial microcosm: new species can arise as frequently as adaptations within a species. ISME J 7:1080-1091

Komárek J (2003) Problem of the taxonomic category "species” in cyanobacteria. Algol Stud 109:281-297

Komárek J (2010) Recent changes (2008) in cyanobacteria taxonomy based on a combination of molecular background with phenotype and ecological consequences (genus and species concept). Hydrobiologia 1:245-259

Komárek J (2011) Introduction to the 18th IAC Symposium in České Budějovice 2010, Czech Republicsome current problems of modern cyanobacteria taxonomy. Fottea 11:1-7

Komárek J, Anagnostidis K (1986) Modern approach to the classification system of cyanophytes 2Chroococcales. Algol Stud 43:157-226

Komárek J, Anagnostidis K (1989) Modern approach to the classification system of cyanophytes 4Nostocales. Algol Stud 56:247-345

Komárek J, Anagnostidis K (1998) Cyanoprokaryota 1. Teil: Chroococcales. In: Ettl H, Gärtner G, Heynig H, Mollenhauer D (eds) Süsswasserflora von Mitteleuropa 19/1. Gustav Fischer, Jena-StuttgartLübeck-Ulm

Komárek J, Sant'Anna C, Bohunická M, Mareš J, Hentschke GS, Rigonato J, Fiore M (2013) Phenotype diversity and phylogeny of selected Scytonema-species (Cyanoprokaryota from SE Brazil). Fottea 13:173-200

Komárek J, Kaštovský J, Mareš J, Johansen JR (2014) Taxonomic classification of cyanoprokaryotes (cyanobacterial genera) 2014 using a polyphasic approach. Preslia 86:295-335

Komárková J, Zapomělová E, Komárek J (2013) Chakia (cyanobacteria), a new heterocystous genus form Belizean marshes identified on the basis of the 16S rRNA gene. Fottea 13:227-233

Konstantinidis KT, Tiedje JM (2005) Genomic insights that advance the species definition for prokaryotes. Proc Natl Acad Sci USA 102:2567-2572

Konstantinidis KT, Ramette A, Tiedje JM (2006) The bacterial species definition in the genomic era. Philos Trans R Soc Lond B Biol Sci 361:1929-1940

Kopac S, Wang Z, Wiedenbeck J, Sherry J, Wu M, Cohan FM (2014) Genomic heterogeneity and ecological speciation within one subspecies of Bacillus subtilis. Appl Environ Microbiol 80:4842-4853

Li R, Watanabe MM (2004) Fatty acid composition of planktonic species of Anabaena (cyanobacteria) with coiled trichomes exhibited a significant taxonomic value. Curr Microbiol 49:376-380

Litvaitis MK (2002) A molecular test of cyanobacterial phylogeny: inferences from constraint analyses. Hydrobiology 468:135-145

Lodders N, Stackebrandt E, Nubel U (2005) Frequent genetic recombination in natural populations of the marine cyanobacterium Microcoleus chthonoplastes. Environ Microbiol 7:434-442

Maiden MC, Bygraves JA, Feil EJ et al (1998) Multilocus sequence typing: a portable approach to the identification of clones within populations of pathogenic microorganisms. Proc Natl Acad Sci USA 95:3140-3145

Marston MF, Pierciey FJ Jr, Shepard A, Gearin G, Qi J, Yandava C, Schuster SC, Henn MR, Martiny JB (2012) Rapid diversification of coevolving marine Synechococcus and virus. Proc Natl Acad Sci USA 109:4544-4549

Martiny JBH, Bohanna BJM, Brown JH et al (2006) Microbial biogeography: putting microorganisms on the map. Nat Rev Microbiol 4:102-112

Mayr E (1942) Systematics and the origin of species from the viewpoint of a zoologist. Columbia University Press, New York

Mayr E (1946) What is a species, and what is not? Philos Sci 63:262-277 
Mazard S, Ostrowski M, Partensky F, Scanlan DJ (2012) Multi-locus sequence analysis, taxonomic resolution and biogeography of marine Synechococcus. Environ Microbiol 14:372-386

Melendrez MC, Lange RK, Cohan FM, Ward DM (2011) Influence of molecular resolution on sequencebased discovery of ecological diversity among Synechococcus populations in an alkaline siliceous hot spring microbial mat. Appl Environ Microbiol 77:1359-1367

Mes TH (2008) Microbial diversity—insights from population genetics. Environ Microbiol 10:251-264

Miller KR, Jacob JS, Burger-Wiersma T, Matthijs HC (1988) Supramolecular structure of the thylakoid membrane of Prochlorothrix hollandica: a chlorophyll $b$-containing prokaryote. J Cell Sci 91:577-586

Miller SR, Castenholz RW, Pedersen D (2007) Phylogeography of the thermophilic cyanobacterium Mastigocladus laminosus. Appl Environ Microbiol 73:4751-4759

Morden CW, Golden SS (1989) psbA genes indicate common ancestry of prochlorophytes and chloroplasts. Nature 337:382-385

Mühlsteinová R, Johansen JR, Pietrasiak N, Martin MP, Osoirio-Santos K, Warren SD (2014) Polyphasic characterization of Trichocoleus desertorum sp. nov. (Pseudanabaenales, Cyanobacteria) from desert soils and phylogenetic placement of the genus Trichocoleus. Phytotaxa 163:241-261

Nabout JC, da Silva Rocha B, Carneiro FM, Sant'Anna CL (2013) How many species of Cyanobacteria are there? Using a discovery curve to predict the species number. Biodivers Conserv 22:2907-2918

Nakhleh L (2013) Computational approaches to species phylogeny inference and gene tree reconciliation. Trends Ecol Evol 28:719-727

NarechaniaA Baker RH, Sit R, Kolokotronis SO, DeSalle R, Planet PJ (2012) Random addition concatenation analysis: a novel approach to the exploration of phylogenomic signal reveals strong agreement between core and shell genomic partitions in the cyanobacteria. Genome Biol Evol 4:30-43

Nürnberg DJ, Mariscal V, Parker J, Mastroianni G, Flores E, Mullineaux CW (2014) Branching and intercellular communication in the Section V cyanobacterium Mastigocladus laminosus, a complex multicellular prokaryote. Mol Microbiol 91:935-949

Oksanen J, Blanchet FG, Kindt R, Legendre P et al. (2013) Vegan: community ecology package. R package version 2.0-10. http://CRAN.R-project.org/package=vegan

Oren A (2004) A proposal for further integration of the cyanobacteria under the Bacteriological Code. Int J Syst Evol Microbiol 54:1895-1902

Oren A (2011) Cyanobacterial systematics and nomenclature as featured in the International Bulletin of Bacteriological Nomenclature and Taxonomy/International Journal of Systematic Bacteriology/International Journal of Systematic and Evolutionary Microbiology. Int J Syst Evol Microbiol 61:10-15

Oren A, Garrity GM (2014) Then and now: a systematic review of the systematics of prokaryotes in the last 80 years. Antonie Van Leeuwenhoek 106:43-56

Oren A, Tindall BJ (2005) Nomenclature of the cyanophyta/cyanobacteria/cyanoprokaryotes under the International Code of Nomenclature of Prokaryotes. Algol Stud 117:39-52

Osorio-Santos K, Pietrasiak N, Bohunická M, Miscoe LH, Kovácik L, Martin MP, Johansen JR (2014) Seven new species of Oculatella (Pseudanabaenales, Cyanobacteria). Eur J Phycol 49:450-470

Papke RT, Ramsin NB, Bateson MM, Ward DM (2003) Geographical isolation in hot spring cyanobacteria. Environ Microbiol 5:650-659

Perkerson RB, Johansen JR, Kováčik L, Brand J, Kaštovský J, Casamatta DA (2011) A unique pseudanabaenalean (cyanobacteria) genus Nodosilinea gen. nov. based on morphological and molecular data. J Phycol 47:1397-1412

Pinevich AV, Averina SG, Velichko NV (1997) Another view on the role of photosynthetic pigments in taxonomy of oxygenic-phototrophic bacteria: proposed rejection of the order Prochlorales Florenzano, Balloni, and Materassi 1986 (emend. Burger-Wiersma, Stal, and Mur 1989), the Family Prochloraceae Florenzano, Balloni, and Materassi 1986, and family Prochlorotrichaceae Bruger-Wiersma, Stal, and Mud 1989. Int J Syst Bacteriol 47:1264-1267

Polz MF, Alm EJ, Hanage WP (2013) Horizontal gene transfer and the evolution of bacterial and archeal population structure. Trends Genet 29:170-175

Popa O, Hazkani-Covo E, Landan G, Martin W, Dagan T (2011) Directed networks reveal genomic barriers and DNA repair bypasses to lateral gene transfer among prokaryotes. Genome Res 21:599-609

Preheim SP, Timberlake S, Polz MF (2011) Merging taxonomy with ecological population prediction in a case study of Vibrionaceae. Appl Environ Microbiol 77:7195-7206

R Development Core Team (2013) R: a language and environment for statistical computing. The R Foundation for Statistical Computing, Vienna, Austria. Available at http://www.R-project.org/

Ramette A, Tiedje JM (2007) Biogeography: and emerging cornerstone for understanding prokaryotic diversity, ecology and evolution. Microb Ecol 53:197-207

Reno ML, Held NL, Fields CJ, Burke PV, Whitaker RJ (2009) Biogeography of the Sulfolobus islandicus pan-genome. Proc Natl Acad Sci USA 106:8605-8610 
Řezanka T, Dor I, Prell A, Dembitsky VM (2003) Fatty acid composition of six freshwater wild cyanobacterial species. Folia Microbiol 48:71-75

Richter M, Roselló-Móra R (2009) Shifting the genomic gold standard for the prokaryotic species definition. Proc Natl Acad Sci USA. doi:10.1073/pnas.0906412106

Rippka R, Deruelles J, Waterbury JB, Herdman M, Stanier RY (1979) Generic assignments, strain histories and properties of pure cultures of cyanobacteria. J Gen Microbiol 111:1-61

Robertson BR, Tezuka N, Watanabe M (2001) Phylogenetic analyses of Synechococcus strains (cyanobacteria) using sequences of $16 \mathrm{~S}$ rDNA and part of the phycocyanin operon reveal multiple evolutionary lines and reflect phycobilin content. Int J Syst Evol Microbiol 51:861-871

Rodriguez-Valera F, Martin-Cuadrado AB, Rodriguez-Brito B, Pasic L, Thingstad TF, Rohwer F, Mira A (2009) Explaining microbial population genomics through phage predation. Nat Rev Microbiol 7:828-836

Sabehi G, Shaulov L, Silver DH, Yanai I, Harel A, Lindell D (2012) A novel lineage of myoviruses infecting cyanobacteria is widespread in the oceans. Proc Natl Acad Sci USA 109:2037-2042

Sant́Anna CL, Azevedo MTP, Agujaro LF, Carvalho MC, Carvalho LR, Souza RCR (2006) Manual ilustrado para identificação e contagem de cianobactérias planctônicas de águas continentais brasileiras, 1st edn. Editora Interciência, Rio de Janeiro

Schirrmeister BE, de Vos JM, Antonelli A, Bagheri HC (2013) Evolution of multicellu-larity coincided with increased diversification of cyanobacteria and the great oxidation event. Proc Natl Acad Sci USA 110:1791-1796

Schopf JW (2000) The fossil record: tracing the roots of the cyanobacterial lineage. In: Whitton BA, Potts M (eds) The ecology of cyanobacteria: their diversity in time and space. Springer, Berlin

Seckbach J (2007) Algae and Cyanobacteria in extreme environments. In: Seckbach J (ed) Cellular origin, life in extreme habitats and astrobiology, vol 11. Springer Science \& Business Media, New York, pp $1-811$

Shapiro BJ, Friedman J, Cordero OX et al (2012) Population genomics of early events in the ecological differentiation of bacteria. Science 336:48-51

Shi T, Falkowski PG (2008) Genome evolution in cyanobacteria: The stable core and the variable shell. Proc Natl Acad Sci USA 105:2510-2515

Shih PM, Wu D, Latifi A et al (2013) Improving the coverage of the cyanobacterial phylum using diversitydriven genome sequencing. Proc Natl Acad Sci USA 110:1053-1058

Shishido TK, Kaasalainen U, Fewer DP et al (2013) Convergent evolution of [D-Leucine ${ }^{1}$ ] microcystin-LR in taxonomically disparate cyanobacteria. BMC Evol Biol 13:86

Siegesmund MA, Johansen JR, Karsten U, Friedl T (2008) Coleofasciculus gen. nov. (cyanobacteria): morphological and molecular criteria for revision of the genus Microcoleus Gomont. J Phycol 44:1572-1585

Simpson GG (1953) The major features of evolution. Columbia University Press, New York

Smillie CS, Smith MB, Friedman J, Cordero OX, David LA, Alm EJ (2011) Ecology drives a global network of gene exchange connecting the human microbiome. Nature 480:241-244

Stacerbrandt E, Goebel BM (1994) Taxonomic note: a place for DNA-DNA reassociation and 16S rRNA sequence analysis in the present species definition in bacteriology. Int J Syst Bacteriol 44:846-849

Stackebrandt E, Ebers J (2006) Taxonomic parameters revisited: tarnished gold standards. Microbiol Today 33:152-155

Stackebrandt E, Frederiksen W, Garrity GM et al (2002) Report of the ad hoc committee for the reevaluation of the species definition in bacteriology. Int J Syst Evol Microbiol 52:1043-1047

Staley JT (2006) The bacterial species dilemma and the genomic-phylogenetic species concept. Philos Trans R Soc Lond B Biol Sci 361:1899-1909

Stanier RY, Sistrom WR, Hansen TA et al (1978) Proposal to place the nomenclature of the cyanobacteria (blue-green algae) under the rules of the international code of nomenclature of bacteria. Int $\mathbf{J}$ Syst Bacteriol 28:335-336

Starmach K (1966) Cyanophyta-sinice. Panstwowe Wydawnictwo Naukowe, Warszawa

Stewart EJ (2012) Growing unculturable bacteria. J Bacteriol 196:4151-4160

Strunecký O, Elster J, Komárek J (2011) Taxonomic revision of the freshwater cyanobacterium "Phomidium" murrayi $=$ Wilmottia murrayi. Fottea 11:57-71

Strunecký O, Komárek J, Šmarda J (2014) Kamptonema (Microcoleaceae, Cyanobacteria), a new genus derived from the polyphyletic Phormidium on the basis of combined molecular and cytomorphological markers. Preslia 86:193-207

Sullivan MB, Huang KH, Ignacio-Esponoza JC et al (2010) Genomic analysis of oceanic cyanobacterial myoviruses compared with T4-like myoviruses from diverse hosts and environments. Environ Microbiol 12:3035-3056 
Van Gremberghe I, Leliaert F, Mergeay J, Vanormelingen P, Van der Gucht K, Debeer AE, Lacerot G, De Meester L, Vyverman W (2011) Lack of phylogeographic structure in the freshwater cyanobactrium Microcystis aeruginosa suggests global dispersal. PLoS One. doi:10.1371/journal.pone.0019561

Venables WN, Ripley BD (2002) Modern applied statistics with S, 4th edn. Springer, New York

Whitton BA, Potts M (2000) The ecology of cyanobacteria. Their diversity in time and space. Springer, Berlin

Wiedenbeck J, Cohan FM (2011) Origins of bacterial diversity through horizontal genetic transfer and adaptation to new ecological niches. FEMS Microbiol Rev 35:957-976

Zammit G, Billi D, Albertano P (2012) The subaerophytic cyanobacterium Oculatella subterranea (Oscillatoriales, Cyanophyceae) gen. et sp. nov.: a cytomorphological and molecular description. Eur J Phycol 47:341-354

Zhaxybayeva O, Gogarten JP (2004) Cladogenesis, coalescence and the evolution of the three domains of life. Trends Genet 20:182-187

Zheng Q, Jiao N, Zhang R, Wei J, Zhang F (2014) The evolutionary divergence of psbA gene in Synechococcus and their myoviruses in the East china Sea. PLoS One 9:e86644. doi:10.1371/journal.pone. 0086644 